\title{
Biological Evaluation of Crude and Degummed Oil from Moringa oleifera Seeds
}

\author{
Graziela de Fátima Andrade ${ }^{1}$, Tânia Márcia Sacramento Melo ${ }^{2 *}$, Cláudia Dumans \\ Guedes $^{2}$, Kátia Monteiro Novack², Rinaldo Cardoso dos Santos ${ }^{3}$ and Marcelo Eustáquio \\ Silva $^{3}$ \\ ${ }^{I}$ Escola de Farmácia; Universidade Federal de Ouro Preto; Ouro Preto - $M G$ - Brasil. ${ }^{2}$ Departamento de Química; \\ Instituto de Ciências Exatas e Biológicas; Universidade Federal de Ouro Preto; Ouro Preto - MG - Brasil. ${ }^{3}$ Escola \\ de Nutrição; Universidade Federal de Ouro Preto; 35400-000; Ouro Preto - MG - Brasil
}

\begin{abstract}
The aim of this work was to evaluate the oil extracted from Moringa oleifera (fam. Moringaceae) seeds from the nutritional standpoint. Nutritional evaluation of crude or degummed moringa oil or soybean oil (as a control) involved the determination of the Food Efficiency $(F E)$ in male Fisher rats and the fatty acid composition of the moringa oil. Hepatic and renal functions were assessed by measuring serum transaminases activity and urea and creatinine concentrations, respectively. Serum cholesterol and triglycerides, alkaline phosphatase, total proteins and albumine were also measured. Results showed that FE was slightly increased by the crude moringa oil while no differences were found between the soybean and degummed moringa oil regarding this parameter. Renal or hepatic injures as well as major alterations in serum proteins were not induced by the tested oils. These results suggested that degummed M. oleifera oil possessed adequate biological quality as compared to the crude oil.
\end{abstract}

Key words: Moringa oleifera oil, degummed oil, biological evaluation

\section{INTRODUCTION}

Moringa oleifera (fam. Moringaceae) is a widely cultivated species originated from north-west India that can be exploited both in irrigated and in dry conditions and that presents a high potential due to its multiplicity of uses in food, cosmetics, medicinal and other industrial applications (Lorenzi and Matos., 2002; Silva and Kerr., 1999; Correa, 1998; Matos., 1998; Ramachandran et al., 1980). Nutritional value of its leaves has been recently reviewed and revealed it to be a good source of protein, iron, calcium, vitamins $\mathrm{A}$ and $\mathrm{C}$ when compared with other plant foods such as cassava, amaranth, carrot and mango (Ferreira et al., 2008). The oil extracted from its seeds (known as ben or behen oil due to the high behenic acid content) has a $38-40 \%$ yield and can be used as a food, a cosmetic and a lubricant (Banerji et al., 2009). The refined oil is clear, odorless, and rancid-resistant. Seed biomass remaining after the oil extraction can be used as a fertilizer or a flocculating agent for water purification (Silva and Matos., 2008; Ferreira et al., 2008; Muyibi et al., 2002). The oil extracted from M. oleifera seeds is regarded as having a good commercial interest due to its physical, chemical and pharmacological characteristics (Fahey, 2005), although data on its nutritional value are not

*Author for correspondence: tania@iceb.ufop.br 
available. Based on these premises, a biological evaluation of crude and degummed oil extracted from $M$. oleifera seeds was performed aiming at investigating its potential nutritional quality.

\section{MATERIALS AND METHODS}

\section{$A$ - Moringa oleifera oil}

The seeds were obtained from Patos, Paraíba-Brazil. Oil extractions were performed in a Soxhlet apparatus using hexane as a solvent. For diets preparation, both crude and degummed oils were used. Degumming was done by heating the oil at $70^{\circ} \mathrm{C}$, adding $20 \%(\mathrm{w} / \mathrm{w})$ of water and agitation for 20 minutes. The insoluble fraction was separated by centrifugation aiming at removing the gums (phosphatides, proteins and colloidal substances) (Tsakins et al, 1998).

\section{B- Animals}

Thirty two 23-day old male Fisher rats were housed in individual cages and kept under controlled conditions of temperature and humidity with a light/dark cycle of 12-12 h. Diets and water were offered ad libitum for 28 days and food consumption was monitored weekly. The project was approved by the Ethical Committee of the Federal University of Ouro Preto (decision 036/2008).

\section{C-Biological evaluation}

For the biological evaluation, three types of diets were prepared: a standard one, containing soybean oil (control group), and the test diets containing the crude or the degummed oil. The animals were divided randomly in the groups of eight rats each: Soybean (S), Crude oil (CO) and Degummed oil (DO). Diets (Table 1) were prepared according to AOAC (1992) and stored under refrigeration (0 $4^{\circ} \mathrm{C}$ ) for not more than seven days.

\section{D - Food efficiency}

The food efficiency was calculated by dividing the weight gain by food intake (x 100) after 28 days for each animal.

\section{E - Protein determination}

Protein content of the casein was measured by the semi-micro Kjeldahl method according to AOAC (1992). The factor 6.25 was employed to convert the nitrogen into protein.

Table 01 - Diets composition. Groups: soybean (S), crude oil (CO) and degummed oil (DO).

\begin{tabular}{|c|c|c|c|}
\hline \multicolumn{4}{|c|}{ Diets } \\
\hline Ingredients & $\mathbf{S}(\mathrm{g})$ & $\mathrm{CO}(\mathrm{g})$ & DO \\
\hline Casein & 133.0 & 133.0 & 133.0 \\
\hline Fiber & 10.0 & 10.0 & 10.0 \\
\hline Soybean oil & 80.0 & - & - \\
\hline Crude oil & & 80.0 & . \\
\hline Degummed oil & - & - & 80.0 \\
\hline Salt Mixture & 50.0 & 50.0 & 50.0 \\
\hline Vitamin mixture & 10.0 & 10.0 & 10.0 \\
\hline Choline & 2.0 & 2.0 & 2.0 \\
\hline Corn starch & q.s.p. 1000.0 & q.s.p. 1000.0 & q.s.p. 1000.0 \\
\hline
\end{tabular}

\section{F-Biochemical determinations}

After 28 days, the animals were fasted overnight and anesthetized with ether for blood removal through the orbital plexus. Total cholesterol, triglycerides, albumin, total proteins, hemoglobin, transaminases, alkaline phosphatase (ALP), urea and creatinine were determined using the commercial kits (Labtest, Lagoa Santa, MG, Brazil).

\section{G-Fatty acids analysis}

The analysis of fatty acids was performed by the gas chromatography using a SHIMADZU GCMSQP5050A equipment with a capillary column DB5 (30m $\times 0,25 \mathrm{~mm} \times 0,25 \mu \mathrm{m})$, using the respective methyl esters. The relative retention time with those of the standards (Sigma Aldrich Co, USA) was used to identify the fatty acids and the area under each peak in the chromatogram was employed to determine the relative percentage of each substance.

\section{H- Statistical analysis}

Statistical analysis of data was done by one-way ANOVA. When $p<0.05$. Tukey's test was done to determine the specific differences between the means (Snedecor and Cochran, 1971). 


\section{RESULTS AND DISCUSSION}

Despite having its leaves been extensively studied for its medicinal and nutritional properties (Ferreira et al., 2008; Broin, 2007), the moringa tree has not had its oil biologically investigated so far. The fatty acids found in the crude moringa oil were (with the respective percentage): palmitic 16:0 (9.61), palmitoleic 16:1 (2.78), estearic 18:0 (8.70), oleic 18:1 (66.26), 9-nonadecenoic 19:1 (2.52), arachidic 20:0 (3.59), behenic 22:0 (5.39) and lignoceric 24:0 (1.17\%). Banerji et al (2009), examining the oil from different clones of Indian moringa, found similar result but with interesting differences: oleic acid was the most prevalent fatty acid, as in the present study, but their saturated/unsaturated ratio was 0.234 against 0.351 obtained here. However, no behenic acid was found by those authors. On the other hand, the unusual 9-nonadecenoic acid was present in the oil of Brazilian moringa but not in that of Indian seeds; linoleic and linolenic acids were absent in the present study.

The nutritional analysis showed that the crude oil slightly increased the food efficiency of the animals $(24.7 \pm 0.22 \%)$ while no significant difference was found between the groups fed soybean $(23.5 \pm 0.16 \%)$ or degummed moringa oils $(21.5 \pm 0.15 \%)$. These results indicated that the tested oils did not contain any substance that could adversely affect the animals during the experimental period.

Table 2 - Serum parameters of rats receiving diets with soybean oil (S), and crude (CO) or degummed (DO) $M$. oleifera oils ${ }^{(1)}$.

\begin{tabular}{|c|c|c|c|}
\hline & $S$ & $\mathrm{CO}$ & $\mathrm{DO}$ \\
\hline Total cholesterol (mg/dL) & $82.95 \pm 8.92^{(\mathrm{A})}$ & $71.76 \pm 6.86^{(\mathrm{A})}$ & $79.71 \pm 11.43^{(\mathrm{A})}$ \\
\hline HDL (mg/dL) & $62.84 \pm 10.06^{(\mathrm{A})}$ & $61.67 \pm 5.62^{(\mathrm{A})}$ & $64.51 \pm 14.45^{(\mathrm{A})}$ \\
\hline Triglycerides (mg/dL) & $59.07 \pm 14.19^{(\mathrm{A})}$ & $117.87 \pm 15.09^{(\mathrm{C})}$ & $81.39 \pm 16.53^{(\mathrm{B})}$ \\
\hline $\operatorname{AST}^{(2)}(\mathrm{u} / \mathrm{mL})$ & $27.81 \pm 4.38^{(\mathrm{A})}$ & $27.48 \pm 2.74^{(\mathrm{A})}$ & $23.70 \pm 9.58^{(\mathrm{A})}$ \\
\hline $\operatorname{ALT}^{(3)}(\mathrm{u} / \mathrm{mL})$ & $15.64 \pm 2.67^{(\mathrm{A})}$ & $15.72 \pm 2.65^{(\mathrm{A})}$ & $17.51 \pm 2.78^{(\mathrm{A})}$ \\
\hline Alkaline phosphatase (u/L) & $72.63 \pm 18.64^{(\mathrm{A})}$ & $47.40 \pm 16.33^{(\mathrm{B})}$ & $67.04 \pm 18.94^{(\mathrm{A})}$ \\
\hline Total proteins (g/dL) & $5.32 \pm 0.17^{(\mathrm{A})}$ & $5.61 \pm 0.16^{(\mathrm{B})}$ & $5.42 \pm 0.18^{(\mathrm{A})}$ \\
\hline Albumine (g/dL) & $2.84 \pm 0.09^{(\mathrm{A})}$ & $3.18 \pm 0.19^{(\mathrm{A})}$ & $3.10 \pm 0.17^{(\mathrm{A})}$ \\
\hline Creatinine (mg/dL) & $0.55 \pm 0.05^{(\mathrm{A})}$ & $0.68 \pm 0.06^{(\mathrm{B})}$ & $0.63 \pm 0.04^{(\mathrm{B})}$ \\
\hline Urea $(\mathrm{mg} / \mathrm{dL})$ & $18.27 \pm 6.66^{(\mathrm{A})}$ & $15.90 \pm 2.68^{(\mathrm{A})}$ & $16.49 \pm 3.25^{(\mathrm{A})}$ \\
\hline Hemoglobin $(\mathrm{g} / \mathrm{dL})$ & $12.09 \pm 0.99^{(\mathrm{A})}$ & $12.25 \pm 1.08^{(\mathrm{A})}$ & $12.67 \pm 0.95^{(\mathrm{A})}$ \\
\hline
\end{tabular}

The moringa oil contains a diversity of fatty acids that enables it to fulfill the needs of the animals in the 28-day assay (Banerji et al., 2009; Elkhalifa et al., 2007). A similar pattern was observed by Manorama and Rukmini (1991), when studying the performance of crude palm oil in the rats in equivalent conditions. Other unusual oils, such as coriander (Mironova et al., 1991) and grape seed (Mironova et al., 1990) were studied using the rats and both were shown to be equivalent to sunflower oil as far as biological properties were concerned. On the other hand, a meal prepared with the whole moringa seeds induced deleterious effects in the animals that took the diet containing the meal (Oliveira et al., 1999). Perhaps the water soluble anti-physiological factor(s) responsible for those effects were not carried when the oil was extracted from the seeds. As a matter of fact water soluble lectins with hemagglutinating activity for rabbit erythrocytes were identified in moringa seeds, for instance (Santos et al., 2005). In addition, serum alkaline phosphatase activity (Table 2) was lower in the animals consuming the crude oil diet possibly due to the metal-lowering action of substances such as phytates found in the moringa seeds (Ferreira et al., 2008). When the degummed oil was given to the animals, ALP activity was comparable to the control values, indicating the beneficial effect of the degumming process. When comparing other serum parameters of the rats fed with the diets containing soybean and moringa oils, no difference was found in the total and in HDL-cholesterol. Triglycerides were augmented in the animals fed with the tested oils. A similar result was found by Manorama and Rukmini (1991) when testing the crude and refined palm oils against the groundnut oil in the rats during 28 days. Nevertheless, when the animals were 
examined after 90 days of experiment, the TG values were statistically equal amongst all the groups. The reasons for this remain to be established, especially when one takes into consideration that the increase in the TG was more pronounced with the crude than with the degummed moringa oil-fed rats. Again the degumming process might have played a role in improving the nutritional quality of the moringa oil. Transaminases activity was not altered by the moringa oils, which showed that no liver damage was caused by these. Albumin synthesis by the liver was not affected by the ingestion of both the moringa oils and only a discrete increase in the total protein was found in the serum of $\mathrm{CO}$ animals, possibly due to the increase, although not significant, in serum albumine in these rats. The renal function of the rats was assessed by serum creatinine and urea concentrations. While the first was augmented in the moringa oil-fed rats, urea had similar values amongst all the groups. This indicated that no renal injure was apparently induced by the tested oils, although the discrepancy between the two parameters demanded further investigation.

These results suggested that the degummed M.oleifera oil had adequate biological quality as compared to the crude oil.

\section{ACKNOWLEDGEMENTS}

The authors thank FAPEMIG for the financial support.

\section{REFERENCES}

AOAC (1992), Official methods of analysis of AOAC International, Association of Official Analytical Chemists. 12th ed., Washington, D.C.

Banerji, R. et al. (2009), Oil and fatty acid diversity in genetically variable clones of Moringa oleifera from India. J. Oleo Science, 58 (1), 9-16.

Broin, M.(2007), The nutritional value of Moringa oleifera Lam leaves: what can we learn from figures. Moringa News,

http://www.moringanews.org/doc/GB/Posters/Broin_pos ter.pdf, accessed in 03/24/2009.

Correa, M. P. (1984), Dicionário das plantas úteis do Brasil e das exóticas cultivadas. Rio de Janeiro, MA/IBDF, 5.

Elkhalifa, A. E. O., Ahmed, S. A. A., Adam, S. (2007), Nutritional evaluation of Moringa Oleifera leaves and extract. Ahfad Journal, http://www.articlearchives.com/medicine-health/dietnutrition-fitness/1903437-1.html acesso em 30 mar2009.

Fahey, J. W. (2005), Moringa oleifera: A Review of the Medical Evidence for its Nutritional, Therapeutic, and Prophylactic Properties. Part 1. Trees for Life Journal: a forum on beneficial trees and plants. 1:5 http://www.TFLJournal.org/article.php/2005120112493 1586

Ferreira, P.M. P. et al (2008), Moringa oleifera: bioactive compounds and nutritional potential. Rev. Nutr, 21 (4), 431-437.

Lorenzi, H.; Matos, F. J. A. (2002), Plantas medicinais no Brasil: nativas e exóticas cultivadas. Nova Odessa: Instituto Plantarum, 347.

Manorama, R..; Rukmini, C. (1991), Nutritional evaluation of crude palm oil in rats. Am. J. Clin. Nutr. 53, 1031S$1033 \mathrm{~S}$.

Matos, F. J. A. (1998), Farmácias vivas: sistemas de utilização de plantas medicinais projetado para pequenas comunidades. 3. ed. Fortaleza: EUFC, 220.

Minorova, A. N.; Filippova, G.I.; Fedina, N.I.; Volkova, Z.D.; Kozlova, V. L.; Alymova, T. B.; Gorshkova, E. I.; Bykova, S. F. (1991), Chemical and biological properties of coriander fatty oil. Vopr Pitan., 1, 59-62. (By abstract)

Mironova, A.N.; Kozlova, V.L.; Volkova, Z. D.; Filippova, G. I.; Fedina, N. I.; Alymova, T.B.; Vologdina, S. P.; Gorshkova, E.I. (1990), Chemical and biological properties of grape seed oil. Vopr Pitan., 5, 51-3. (By abstract)

Muyibi, S. A.; Mohd, M. J. M.; Noor, T. K. L.; Loon, L. H. (2002), Effects of oil extraction from Moringa oleifera seeds on coagulation of turbid water. Environ. Studies, 59 (2), 243-254.

Oliveira, J. T. A; Silveira, S. B.; Vasconcelos, K. M.; Cavada, B. S.; Moreira, R. A. (1999) Compositional and nutritional attributes of seeds from the multiple purpose tree Moringa oleifera Lamarck J. Sci. Food Agric. 79 (6):815-820.

Ramachandran, C.; Peter, K. V.; Gopalakrishnan, P. K. (1980), Drumstick (Moringa oleifera) a multipurpose Indian vegetable. Economy Botany, [S.1.], 34, 276-283.

Santos, A. F. S.; Argolo, A. C. C.; Coelho, L. C. B.; Paiva, P. M. G. (2005). Detection of water soluble lectin and antioxidant component from Moringa oleifera seeds. Water Res. 39 (6): 975- 980.

Silva, A. R.; Kerr, W. E. (1990), Moringa: uma nova hortaliça para o Brasil. Uberlândia: UFU/DIRIU, 95.

Silva, F. J. A.; Matos, J. E. X. (2008), Sobre dispersões de Moringa oleifera para tratamento de água. Tecnol. Fortaleza, 29 (2), 157-163.

Snedecor, G. W.; Cochran, W. G. (1971), Statistical Methods, $6^{\text {th }}$ ed., The Iowa State University Press, 91275.

Tsakins, J., Lalas, S., Gergis, V., and Spiliolits, V. (1998). A total characterization of Moringa oleifera Malawi seed oil. Riv. Ital. Sost. Gras. 75(1), 21-27.

Received: May 06, 2010; Revised: March 28, 2011; Accepted: August 09, 2011. 